\section{Toxocaral antibodies in personnel occupationally concerned with dogs}

Over 30000 people in the United Kingdom are employed in research using laboratory animals and many of these people have considerable contact with dogs. In 1978 Woodruff et al found a sixfold increase in toxocaral antibodies in dog-fanciers compared with the general population $(15.7 \% v$ $2.6 \%) .{ }^{1}$ Some concern has been expressed that toxocaral infection might be an occupational hazard and a survey was performed of dog exposed personnel engaged in animal husbandry and pharmaceutical research in this organisation (Fisons plc) to discover whether appreciable occupational exposure occurs.

A short questionnaire was administered to the survey population. This covered past and present dog owning, dog worming routines, and history of occupational exposure to dogs. Of the 67 subjects, 66 gave blood that was examined for eosinophilia and toxocaral antibodies using the method of de Savigny et al. ${ }^{2}$ Atmospheric sampling during cleaning of dog accommodation by high speed water jets was carried out to discover whether aerosols containing toxocaral ova were created by the cleaning process. For this purpose samples were taken using a Multistage liquid impinger. The samples were examined microscopically and put out on to agar plates for culture.

Sixty eight per cent of the sample had had dogs as pets or were currently dog owners. Of these people, $36 \%$ (24\% of the whole population) had not had their dogs regularly wormed. The mean period of occupational exposure to dogs was 6.5 years. None had abnormal eosinophilia or antibody evidence of current infection. Three people $(4.5 \%)$ had antibody levels indicating past infection, of whom one had been occupationally exposed to dogs for only a few months. No toxocaral ova, bacteria, or other organisms were detected by atmospheric sampling.

The level of toxocaral antibodies found in the survey population $(4.5 \%)$ was much lower than that in dog breeders $(15.7 \%)$ and comparable to that of the general population $(2 \cdot 6 \%)$.

This is all the more remarkable a finding considering the high level of past and present ownership of dogs as pets and the long period of occupational canine exposure in the sample. The important fac- tors that might explain the differences between the sample and the results from dog breeders are intensity and duration of exposure and adherence to worming routines. For many dog fanciers their hobby is a part time activity but for some it may entail 60 or 70 hours' exposure each week. Such a variation in duration of exposure is mirrored in this survey population whose intensity of potential exposure is undoubtedly higher. It is more likely then that the difference is due to worming routines. If this is so it is a considerable vindication of the protective effects of the regular worming routines that have been adhered to in this organisation since 1975.

It has been assumed that most toxocaral infection is passed on by physical contact with dogs or, particularly with children, by canine faecal contamination. It seemed important to rule out the possibility of occupational exposure during animal room cleaning with high speed water jets. The findings are that this wet method does not produce aerosols containing toxocaral ova and is indeed an effective technique for removing bacteria, fungi, and all other types of atmospheric contaminants.

ELISA tests were performed by courtesy of Dr A Voller, Nuffield Laboratory of Comparative Medicine, Regent's Park, London NW1.

AJM SLOVAK Division Medical Officer, Fisons Occupational Health Service, Fisons plc, 12 Derby Road, Loughborough, Leicestershire LE11 OBB, UK

\section{References}

\footnotetext{
' Woodruff AW, de Savigny DH, Jacobs DE. Study of toxocaral infection in dog breeders. Br Med J 1978;ii:1747-8.

${ }^{2}$ de Savigny DH, Voller A, Woodruff AW. Toxocariasis: serological diagnosis by enzyme immunoassay. J Clin Pathol 1979;32:284-8.
}

5th Annual Pulmonary and Critical Care: a practical approach

23 February-2 March 1985 at Park City, Utah.

Accreditation: 22 hours of Category I. Fee: $\$ 350.00$.

For registration information please call: San Francisco (415) 666-5808 and, for programme information: 666-4251. 